\title{
Bush Cree Storytelling Methodology: Northern Stories That Teach, Heal, and Transform
}

\author{
Herman Michell
}

Northern Teacher Education Program/Northern Professional Access College

\begin{abstract}
The purpose of this exploratory paper is to introduce key aspects of Bush Cree storytelling methodology. In this essay, I provide a foundation for further articulation using a Cree worldview framework as an umbrella for northern-based storytelling discourse. The underlying current in this paper makes links to Cree stories that teach, heal, and transform.
\end{abstract}

Keywords: Woodlands Cree; storytelling; methodology

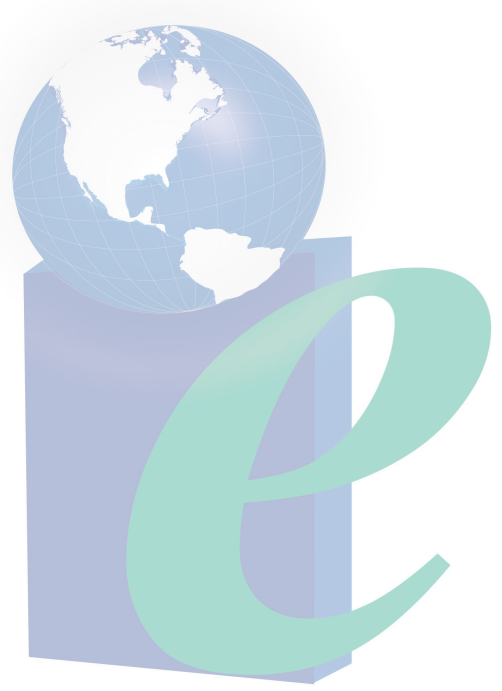




\section{Bush Cree Storytelling Methodology: Northern Stories That Teach, Heal, and Transform}

Moon rays flash through dark clouds across a frozen lake. A blanket of snow glistens like a thousand gems. The North is fully alive at this time of the year. Sacred and mysterious ancient voices from the land travel in whispers through air entering dreams and thoughts of storytellers where there is no beginning and no ending. Winter is a time when certain stories are told in northern Bush Cree trapping families. My thoughts travel back in time. I remember shadows of movement on cabin walls, the smell of wood smoke, and the sounds from fire humming the night into being. The stories would begin. Slowly at first, quietly, picking up momentum at times, thought-provoking words unleashed, followed by inaudible whispers, deep sighs, leaving footprints in minds to interpret. Time blurs in unknown story spaces. Words illuminate a colorful tapestry of people, places, and experiences unfolding into the present. Storytelling is a way of passing on knowledge in many cultures around the world (Kroeber, 2004; Kovach, 2010; Smith, 1999). The purpose of this exploratory paper is to introduce key aspects of Bush Cree storytelling methodology.

According to a study done by MacLean and Wason-Ellam (2006), storytelling is one way of "Indigenizing" the curriculum, telling stories that link with local communities. It is important to provide safe avenues for students to share their stories. The ability to express orally or in written form is healing. Sharing stories validates their identity as social beings in relationship with others within a community. As an author of Woodlands Cree heritage, I remember the evening storytelling moments with my mother. I could listen to her for hours. She had her own storytelling demeanor, no doubt from listening and experiencing stories from her own teachers, the Elders and relatives who live and occupy her storied memory. I could see them by the way she expressed her words, touching my psyche, teaching me, and showing me guidance. Colorado (1988) writes about this sense of "collapsed time" in stories that Indigenous people describe as a temporal, spiritual essence, connecting the past with the present:

When my grandmother used to tell me stories, I would close my eyes and I would feel as if I were walking through that time. I could just imagine everything the way that it looked, the tools that people used, what kind of clothing they wore, how the weather felt, what people were feeling; it all came alive to me! It is as if I was right there at the time. (p. 55)

Cree storytellers have a unique way of using voice, face, and body movements to keep listeners grounded and connected to story. Stories are lived and some are well thought out before they are told. Storylines are formatted with clearly articulated thoughts, links, and impressions. Traditional Cree stories of Wîshâkēchâk, Wîtîgô, and Mîmîkwîsîwâk (Cree mythical beings) are intriguing because they allow one to think deeply while connecting with hidden messages of Cree origins, worldview, and ways of knowing. Cree stories are used to teach history, values, natural laws, and life skills. The following Cree values can be found in oral stories and are used to guide how we think, how we relate to one another, and how to take care of one's self, others, and the natural world: ${ }^{1}$ 


$\begin{array}{ll}\text { Ayâmîhîwâtôsowin } & \text { Spirituality } \\ \text { Tâpowâkēthîtâmowin } & \text { Faith/Truth } \\ \text { Kîsēwâtîsowin } & \text { Love } \\ \text { Wîyâtîkwēthîmowin } & \text { Happiness } \\ \text { Pîkîsowin } & \text { Cleanliness } \\ \text { Kîstēthîtâmowin } & \text { Respect } \\ \text { Nânâhîtâmowin } & \text { Obedience } \\ \text { Tâpahtēthîmowin } & \text { Humility } \\ \text { Nânâskômôwîn } & \text { Thankfulness } \\ \text { Wâhkôhtôwîn } & \text { Kinship/Relations } \\ \text { Opîkîyâsôwîn } & \text { Child rearing } \\ \text { Wîchîtôwîn } & \text { Helping/Sharing } \\ \text { Sôkâtîsôwîn } & \text { Strength } \\ \text { Kânâwèthîmîsôwîn } & \text { Protection } \\ \text { Iyitâtēthîhtâmôwîn } & \text { Hope } \\ \text { Kîskînôtâhsôwîn } & \text { Guiding one’s self } \\ \text { Sîtôskâtôwîn } & \text { Unity } \\ \text { Sîhtwēthîmôwîn } & \text { Seal }\end{array}$

There are other Cree words depending on community, region, and language dialect (Wolvengrey, 2001).

The underlying teachings and lessons within traditional Cree stories can be used to dialogue about contemporary issues and events. Different stories intermingle and blur with contemporary lives and events of people and places. The past connects, verifies, and legitimates other stories in the present, setting in motion an essence of relevance, continuity, and knowledge transmission with core lessons intact. The act of storytelling fosters reciprocal engagement, requiring active listening and sharing. A particular story can be told repeatedly with different meanings and interpretations each time and sometimes teachings reveal themselves years later. Storytellers have unique ways of sharing: using vocal inflections, verbal skills, content omissions, additions, shifts in events, and change in characters (Kroeber, 2004). The voices of ancestors within stories come alive through the energy of the words expressed, metaphors, analogies, and sounds from the land. 
Many Cree stories are tied to the northern landscape where you can actually hear sounds from nature within the language. Cree scholar Neal McLeod (2007) states, "Cree collective memory is anchored in places and landscape. Various place-names within Cree narrative form the basis for a shorthand encoding of experience, of various relationships, and the articulation of core Cree values and worldviews" (p. 19). The Cree have had a long period of cultural and linguistic development within particular regions that give rise to different Cree language dialects. The Woodlands Cree ("th" dialect) live in northern Manitoba and Saskatchewan, the Plains Cree ("y" dialect) to the south, the Swampy Cree (" $n$ " dialect) in the middle of northern Manitoba and Saskatchewan, and the Moose, Attikamek, and East Cree ("r" dialect) in Ontario. According to one theory, the Woodlands Cree moved to their present territories at least four thousand years prior to European contact (Siggens, 2005; Smith, 1987). David Meyer (1987) provides a summary of archeological evidence known as the Selkirk composite and concludes Cree occupation of northern Manitoba can be traced back to the 1200s (c.f. Brightman, 2002, p. 7). However, more recent arrowhead discoveries in Manitoba and Saskatchewan known as the Oxbow complex suggests the Cree were hunting and trapping in the North as far back as 2500 BC (Siggens, 2005).

The Woodlands Cree are originally an oral literate Algonquian language group associated with the Montagnais, Naskapi, Ojibwe, Attikamek, and Beothuk peoples. The term "Cree" originates from the French word Kiristino, which is an Ojibwa name for a division of Creespeaking people south of James Bay in the mid-17th century (Brightman, 2002). Eventually the term transformed into Kri and then the current term Cree. The Cree are the largest and most widespread Indigenous group in Canada. They occupy land in the northern boreal forest parts of Quebec, Ontario, Manitoba, Saskatchewan, Alberta and British Columbia. They also live in cities, towns, and villages across the country. According to the 1996 Canadian census, 76,475 people identified the Cree language as their mother tongue (Steckley \& Cummins, 2001). In northern Saskatchewan, we identify ourselves as Rock Cree people or Nihithawak who traditionally lived along the Churchill River system and its tributaries.

The Cree language is an inseparable part of the Nihithaway Pimitasiwin (Cree way of life). The language reinforces how we see the world and our place in it (Wilson, 2008). Our Cree worldview provides a framework for our beliefs, values, experiences, and knowledge system (Michell, 2005). Cree words used in stories contain teachings. Some stories are considered sacred, such as those shared in ceremonies. Cajete (1994) states the language is sacred because "...the spoken or sung word expressed the spirit and breath of life of the speaker "(p. 33). Language is powered with energies and can move people in different ways. Language is used to express human thought. The words expressed carry a responsibility. Words are known to soothe, instruct, and bring happiness. Words can be used to heal the wounded. Sharing stories and experiences gives voice to the lost and silent. Stories create a community of learners who respect each other's voice. On the contrary, words can also destroy and bring harm if used inappropriately. The use of words through stories must be learned and applied with great respect for they are "connected to the land" and the "four cardinal directions" (Cajete, 1994, p. 53). Rules of sharing are important in storytelling circles. In order to understand Cree language and stories, one has to speak, listen, observe, and be immersed in Cree way of life. Learning the language is not just about memorizing words, phrases, and sentences, although this is a good start; the language must be lived, spoken, and illuminated through stories. Access to Cree knowledge of the natural world requires sustained contact and relationship with the land under 
the guidance of Khittîyâk (Elders) and traditional land users who speak the language in all of its facets (Michell, 2011).

Cree storytelling is one way of passing on knowledge. Listening to stories allows people to engage in deep thinking processes such as critical reflection, predicting, relating, and imagining. We learn by relating the "known to the unknown" as we make sense of the story using previous knowledge and experiences (MacLean \& Wason-Ellam, 2006). Khîtîyâk often use stories when providing guidance. A tone of compassion and humility are key aspects of sharing. When Cree people reflect and share stories about their culture and traditions, they convey the spiritual connections they feel to the places from which they come through their language. The stories give voice to their communities and of spirit that is manifested in the land. Stories shed light on the complexity of Cree thought and our northern land-based identity. In a study by Friesen and Orr (1993), stories shared by teachers of First Nations ancestry in an Aboriginal focused teacher education program in northern Saskatchewan revealed they learned traditional knowledge from their ancestral connection to the land. When they talk about these special places in their languages, they connect their spirit to them through their words, thoughts, and feelings. According to Cajete (1994), "There are key words, phrases, and metaphors that act as signposts to the way we think about the world and ourselves” (p. 45).

There are different types of Cree stories and different types of storytellers. Today, storytellers use different mediums such as technology, videos, music, art, drama, comedy, poetry, painting, writing, photos, plays, puppetry, dancing, drumming, and singing. Storytelling can be used to reinforce mental, spiritual, physical, and emotional development depending on the types of activities planned. Some Cree stories are private and can only be shared by those given that responsibility. There are certain stories that must remain oral. Quite often meaning is lost in translation to the English language. Brightman (2007) identifies two types of stories among the Woodlands Cree: achimowina (regular stories) and achithookiwina (traditional stories). The northern Cree have their own creation story from which all other traditional stories flow. These stories contain deep philosophical principles that are linked to Cree identity. It is these stories that we must turn to in order to heal from colonization and impacts of residential schools. Wisakechak, the Cree trickster/transformer crosses physical and spiritual boundaries to teach us life lessons. Wisakechak teaches us to embrace ambivalence, change, and transformation as a necessary part of survival. Showing respect and helping others are relational values rooted in our Cree creation story. It was Wisakechak with the help of Muskrat who restored the earth after diving into the depths of the lake to grab soil. In this story, everyone makes an attempt and is ready to make a sacrifice. Finally, Muskrat takes the challenge despite the risks involved. The story evokes compassion for others, putting aside individual comforts for the sake of the collective. In our Cree belief system, animals give up their lives for the hunter and thus a deep respect is held for the natural world. Proper protocols are used to honor the sacredness of life. Offerings are made that remind us of the Cree ethic of reciprocity.

Many Cree trappers and hunters are storytellers, and have an intimate knowledge of the land, lakes, and river systems. Their stories contain valuable knowledge of the environment and sustainable ways of living and being. Stories about traditional land use activities are an excellent way of bridging Western science and Cree ways of knowing (Aikenhead \& Michell, 2011; Michell, 2012; Michell, 2013). I remember sitting and listening to trappers when they visited our camp. Complex topics included social, historical, economic, and political issues. Some trappers and hunters use specific Cree words, striking oral phrases, and body nuances to express 
underlying concepts so that people "remember." Lessons and stories on bush etiquette are a matter of survival. Berry picking excursions are times when bear stories are shared so that children do not wander too far away from the group. Storytellers use voice tones, singing, clapping, and sounds of animals, birds, wind, and other aspects of the natural world. A skillful storyteller is one who can work with a variety of memory anchors. The more vivid the story, the more easy it is to retain certain pieces of information. The listener looks for patterns of meaning. Some hunters filter humor into storytelling. Laughter is good medicine. It brings healing and it breathes life into stories. Depending on the age of listeners, naughty stories are always shared with sensitivity. The more seasoned elderly hunters use language in a "tone of voice" that acts as an overall guide on how we share stories in a respectful way. In our Cree belief system, the spiritual breath of Kitchi Munto filters through our words and indeed through the entire circularity of life.

In conclusion, many Bush Cree stories are open-ended, allowing for a diversity of possible meanings with no beginning and no ending. Khîtîyâk teach us humility by disclaiming individual authorship of stories (Michell, 2011). They often say they heard the story from someone else, thereby expunging subjectivity. Many Cree stories are re-workings, refinements, and revisions that result in a sharpness of words and sentences to an increasingly complex meaningfulness. In this paper, I have outlined essential aspects of storytelling within Bush Cree culture. The content is incomplete in order to invite critique and a starting base for others who wish to expand on Cree storytelling discourse. It is through story that our experiences and knowledge of the northern landscape can be shared, taught, and passed on. The energy of stories enters and leaves our inner consciousness and outward into the minds of others in a relational way. Ekosi! 


\section{References}

Aikenhead, G., \& Michell, H. (2011). Bridging cultures: Indigenous and scientific ways of knowing nature. Toronto, ON: Pearson Canada.

Brightman, R. (2002). Grateful prey: Rock Cree human-animal relationships. Regina, SK: Canadian Plains Research Center. First printed in 1993 (University of California Press).

Brightman, R.A. (2007). Acaoohkiwina and Acimowina: Traditional narratives of the Rock Cree Indians. Regina, SK: Canadian Plains Research Center. Cajete, G. (1994). Look to the mountain: An ecology of Indigenous education. Durango, CO: Kivaki Press.

Colorado, P. (1988). Bridging Native and Western science. Convergence, 21(2-3).

Friesen, D.W., \& Orr, J. (1996). Emerging teacher role identity: Northern Aboriginal voices. In N. McLeod (Ed.). Multicultural education: The state of the art national study, (p. 100111).

Kovach, M. (2010). Indigenous methodologies: Characteristics, conversations, and contexts. Toronto, ON: University of Toronto Press.

Kroeber, K. (2004). Native American storytelling: A reader of myths and legends. Malden, MA: Blackwell Publishing.

MacLean, M., \& Wason-Ellam, L. (2006). When Aboriginal and Métis teachers use storytelling as an instructional practice. A grant report to the Aboriginal Education Research Network, Saskatoon, SK: University of Saskatchewan.

McLeod, N. (2007). Cree narrative memory: From treaties to contemporary times. Saskatoon, SK: Purich Publishing Limited.

Meyer, D. (1987). Time depth of the Western Wood Cree occupation of northern Ontario, Manitoba, and Saskatchewan. In W. Cowen (Ed.), Papers of the $18^{\text {th }}$ Algonquin Conference, (pp. x-xx). Ottawa, ON: Carleton University.

Michell, H. (2005). Nēhîthâwâk of Reindeer Lake (Canada): Worldview, epistemology, and relationships with the natural world. Australian Journal of Indigenous Education, 34, p. 33-43. doi: 10.1017/S132601110000394X

Michell, H. (2011). Working with Elders and Indigenous knowledge systems in places of higher learning. Vernon, BC: JC Publishing Ltd.

Michell, H. (2012). School science from the eyes of the Woodlands Cree: Using the Migawap dwelling and traditional values as a guide to plot fundamental key concepts and ideas. The Canadian Journal of Native Studies, 32(2), 19-49. Retrieved from http://search.proquest.com/docview/1498365862?accountid=13480

Michell, H. (2013). Cree ways of knowing and school science. Vernon, B.C.: JC Publishing Ltd.Siggens, M. (2005). Bitter embrace: White society's assault on the Woodland Cree. Toronto, ON: McClelland \& Stewart Ltd. 
Smith, J. (1987). The Western Woods Cree: Anthropological myth and historical reality. In D. Miller, C. Beal, J. Dempsey, \& H. Wesley (Eds.), The first ones: Readings in Indian/Native studies, (pp. X-Xx). Piapot, SK: Saskatchewan Indian Federated College Press.

Smith, L. (1999). Decolonizing methodologies: Research and Indigenous peoples. London, UK: Zed Books.

Steckley, J., \& Cummins, B. (2001). Full circle: Canada's First Nations. Toronto, ON: Prentice Hall.

Wilson, S. (2008). Research is ceremony: Indigenous research methods. Winnipeg, MB: Fernwood Publishing.

Wolvengrey, A. (2001). Nēhiyawēwin: itwewina (Cree Words). Cree-English Dictionary, (Vol I). Saskatoon, SK: Houghton Boston. 